\title{
A new Pseudophoxinus (Teleostei, Cyprinidae) species from Asi River Drainage (Turkey)
}

\author{
Fahrettin Küçük ${ }^{1, \dagger}$, Salim Serkan Güçlül,‡ \\ I Süleyman Demirel University, Eastern Campus, Ë̈irdir Fisheries Faculty, Isparta-Turkey \\ † http://zoobank.org/50084B6D-BEF2-4953-B39B-D618AC621473 \\ † http://zoobank.org/8198016F-FCF4-4582-91F9-F0E98C5DF567 \\ Corresponding author: Fahrettin Kǚ̆ük (fahrettinkucuk@sdu.edu.tr)
}

Academic editor: C. Baldwin | Received 17 December 2013 | Accepted 8 May 2014 | Published 23 May 2014

http://zoobank.org/04292ED9-CA7D-4A99-8762-C1F196A0CA9E

Citation: Küçük F, Güçlü SS (2014) A new Pseudophoxinus (Teleostei, Cyprinidae) species from Asi River Drainage (Turkey). ZooKeys 411: 57-66. doi: 10.3897/zookeys.411.6833

\begin{abstract}
Pseudophoxinus turani sp. n. is described from the İncesu Spring (Hassa-Hatay) drainage of Asi River, Turkey. It is distinguished from other Eastern Mediterranean Region Pseudophoxinus species by a combination of characters: lateral line incomplete, with 12-25 (commonly 16-21) perforated scales and 38-46+2-3 scales in lateral series (commonly 41-44+2-3); 10-11 scale rows between the lateral line and dorsal-fin origin; $3-4$ scale rows between the lateral line and the pelvic-fin origin; dorsal fin with $71 \frac{1}{2}$ branched rays; anal fin commonly with 71/2 branched rays; 8-11 gill rakers on the first branchial arch; dorsal profile markedly convex with marked hump at the nape, ventral profile less convex than dorsal profile; a small, irregular, black blotch on the base of the caudal fin; mouth terminal, with slightly distinct chin, its corner not reaching vertical through anterior margin of eye; snout somewhat long, with rounded tip; and its length greater than eye diameter.
\end{abstract}

\section{Keywords}

Anatolia, Asi River, freshwater fishes, Leuciscinae, taxonomy

\section{Introduction}

Members of the cyprinid genus Pseudophoxinus are small minnows mostly found in cold springs, slow-flowing waters and clean lakes (Küçük et al. 2013). Speciation and phylogenetic relationships within the genus in Anatolia were first studied by Hrbek et al. (2004), 
who argued that the Tohma Stream population (Firat River drainage) (originally published as Pseudophoxinus new species, now P. firati) and P. kervillei from the Asi River form a separate lineage distinct from all other congeners in Central Anatolia, the Lakes Region and Büyük Menderes basins. A more comprehensive and detailed study based on mitochondrial and nuclear DNA data corroborates the hypothesis that the genus Pseudophoxinus is represented in Anatolia by two monophyletic lineages (Central Anatolian and Eastern Mediterranean Region clades) and noted uncertainty in Anatolian Pseudophoxinus species boundaries (Perea et al. 2010).

The original description of the Eastern Mediterranean Region species $P$. kervillei by Pellegrin (1911:109-110, 1928:120-121) includes the following information: lateral line incomplete, 37-42 scales in lateral series, 9-10 scale rows between lateral line and dorsalfin origin, 7-8 scale rows between lateral line and the pelvic-fin origin, D 11, A 10, P 13, V 8. The distribution area originally given as Asi River, Adana and Islahiye near Osmaniye (Pellegrin 1928:121), is restricted to Jordan, Litani and Asi rivers basins according to Krupp (1985), who described a Phoxinellus (=Pseudophoxinus) sp. from Hupnik Stream (near Islahiye, $22 \mathrm{~km}$ southeast Gaziantep), a drainage of Asi River, with a shorter lateral line (0-18 scales vs. 4-27 in P. kervillei), more gill rakers and more branched anal-fin rays. Since then this population hasn't been studied and couldn't be relocated at site during our surveys in June 2012 and October 2013. Bogutskaya (1997:177-178) wrote that the Pseudophoxinus specimens from the Ceyhan River (ZMH 1103: Hamburg Zoological Museum, now P. zekayi) and İncesu Spring (ZMH 8001) (mentioned in the original text as Seyhan tributary, although it is a tributary of Asi) differed from Asi River $P$. kervillei in having more scales in the lateral series (55-60 vs. 35-50 in P. kervillei) and presence of 25-34 perforate scales (4-17 in P. kervillei). Perea et al. (2010) also tentatively identified the Pseudophoxinus population from İncesu Spring (Hassa, Hatay) as $P$. cf. kervillei due to molecular distinction of the population from $P$. kervillei (Asi River).

Our evaluation of morphological features and the distribution areas of Eastern Mediterranean Region species $P$. firati, $P$. kervillei, $P$. zeregi and $P$. zekayi indicates that the İncesu (Hassa, Hatay) specimens represent a new species distinct from the Asi River basin P. kervillei, which is described below.

\section{Materials and methods}

Fish specimens were collected by pulsed DC electrofishing equipment, killed by over anaesthetization and fixed in 5\% formalin. Material is deposited in: IFC-ESUF, Inland Fishes Collection, Eğirdir Fisheries Faculty of Süleyman Demirel University. Counts and measurements follow Kottelat and Freyhof (2007). All measurements were point to point and made with digital calipers $\left(0.01 \mathrm{~mm}\right.$ sensitive). Other metrics include head width ${ }_{1}$ (the distance between the anterior eye margins), head width ${ }_{2}$ (the distance between the posterior eye margins), head width (head width at the nape), head depth ${ }_{1}$ (head depth through the eye), head depth $_{2}$ (head depth at the nape), and the snout width (measured at level of the nostrils). The perforated lateral-line scales were counted from the anteriormost scale (the first one 


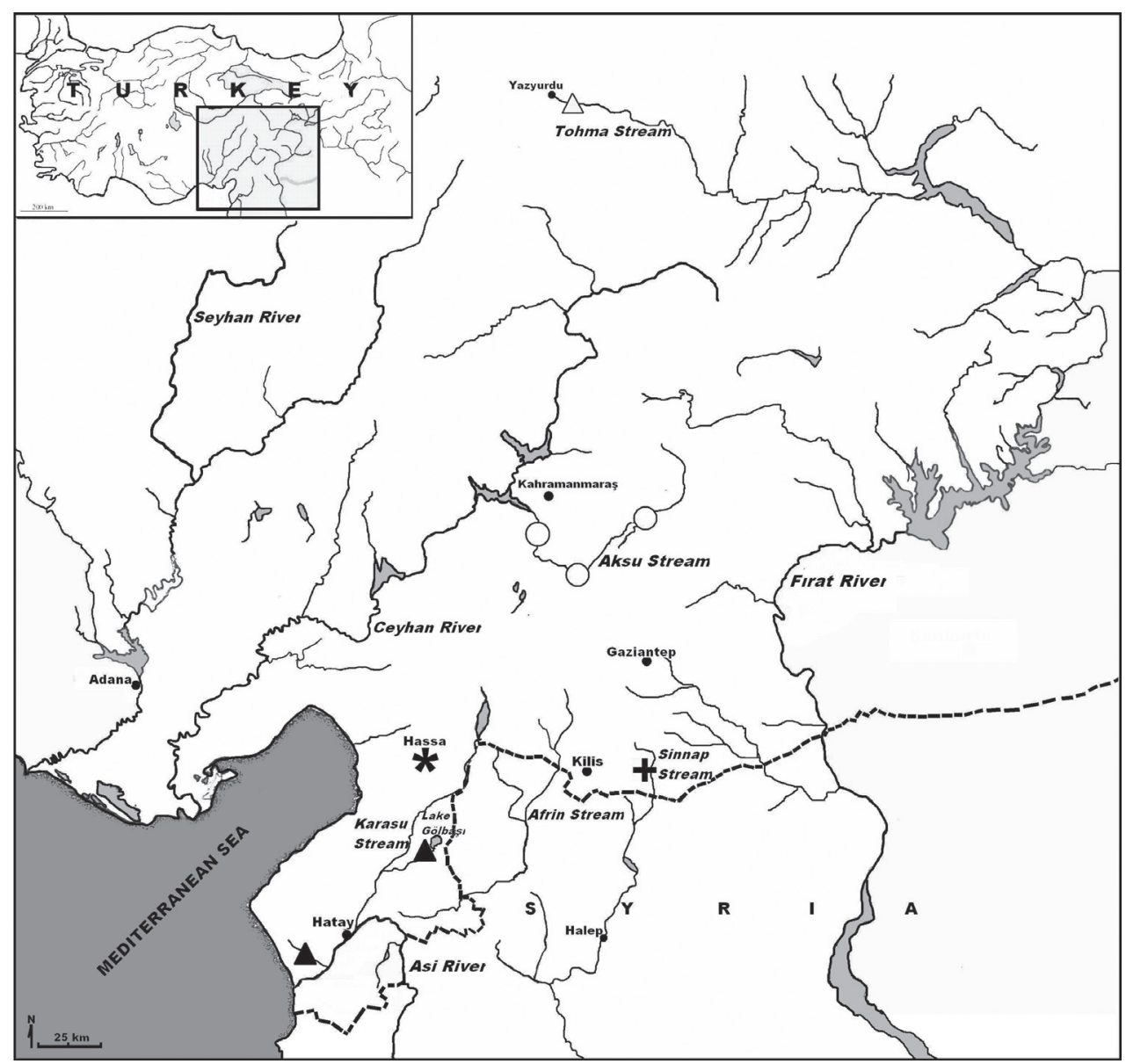

Figure I. Map showing localities of Eastern Mediterranean Region Pseudophoxinus species group $(\triangle P$. firati, $\Delta$ P. kervillei, * P. turani sp. n., O P. zekayi, + P. zeregi).

to touch the shoulder girdle) to the posteriormost one; scales in lateral series were counted along the midlateral line from the first one to touch the shoulder girdle to the last scale at the end of the hypural complex; scales on the caudal fin itself are indicated by "+"; the last two branched dorsal and anal fin rays articulating on a single pterygiophore were counted as $1 \frac{1}{2}$. The vertebral counts were obtained from radiographs and counted following Naseka (1996); abdominal vertebrae were counted from the first Weberian vertebra to the one just anterior to the first caudal vertebra (the most anterior vertebra that has a fully developed haemal spine; the last complex vertebra bearing hypurals was included in the count of total and caudal vertebrae. Cephalic sensory canals were studied under a stereomicroscope.

The morphometric characters of the two species of Pseudophoxinus from Turkey were compared by Principal Component Analysis (PCA) using a covariance matrix on $\log$-transformed measurements and counts with the software package PAST version 1.8 (Hammer et al. 2001). 


\section{Results}

\section{Pseudophoxinus turani sp. n.}

http://zoobank.org/98DF0D2B-6917-44DA-8EAC-E524C0BEB787

http://species-id.net/wiki/Pseudophoxinus_turani

Figures 2, 3

Holotype. IFC-ESUF 03-1002, 71.3 mm SL; Turkey, Hatay Prov., Hassa Country, İncesu Spring, Asi River drainage, 3647.36'N, 36³0.48'E, 20 October 2013, coll. F. Küçük and A. Küçük.

Paratypes. IFC-ESUF 03-1003, 20, 52.1-93.4 mm SL, same as holotype.

Diagnosis. Pseudophoxinus turani is distinguished from all other species of Eastern Mediterranean Region Pseudophoxinus (P. firati, P. kervillei, P. zeregi, P. zekayi) by the following unique combination of characters: head short, its length 26-28\% SL, approximately equal to or slightly shorter than body depth; mouth terminal, with slightly distinct chin, its corner not reaching vertical through anterior margin of eye; eye small, its diameter 25-29\% HL, smaller than snout length; lateral line incomplete, with 12-25 (commonly 16-21) perforated scales and 38-46+2-3 scales in lateral series (commonly 41-44 +2-3); 10-11 scale rows between lateral line and dorsal-fin origin; 3-4 scale rows between lateral line and the pelvic-fin origin; 8-11(rarely 13) gill rakers on the first branchial arch; pharyngeal teeth 5-4, slightly serrated and hooked at tip.

Description (See Figs 2, 3 for general appearance and Tables 1, 2 for morphometric and meristic data). Body deep, its depth at dorsal-fin origin 26-29\% SL, mean 27.8, and laterally compressed. Dorsal profile markedly convex with marked hump at nape, ventral profile less convex than dorsal profile. Dorsal-fin origin situated behind base of pelvic-fin. Predorsal length 56-60\% SL, mean 58.2 and prepelvic length $51-54 \%$ SL, mean 52.4. Head short, its length 26-28\% SL, mean 26.9, approximately equal to or slightly shorter than body depth, upper profile straight or slightly convex on interorbital area and markedly convex on snout. Mouth terminal, with slightly marked chin, its corner not reaching vertical through anterior margin of eye. Eye small, its diameter 25$29 \%$ HL, mean 26.6. Snout somewhat long, with rounded tip, its length 27-31\% HL,

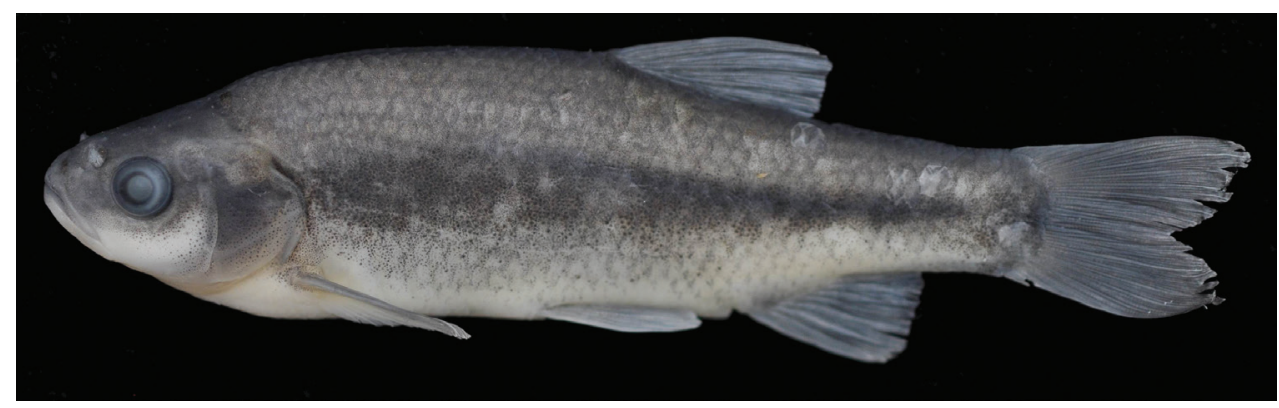

Figure 2. $P$. turani sp. n. holotype, IFC-ESUF 03-1002, $71.3 \mathrm{~mm} \mathrm{SL}$, Turkey: Hatay prov.: Hassa, İncesu Spring, Asi River drainage. 


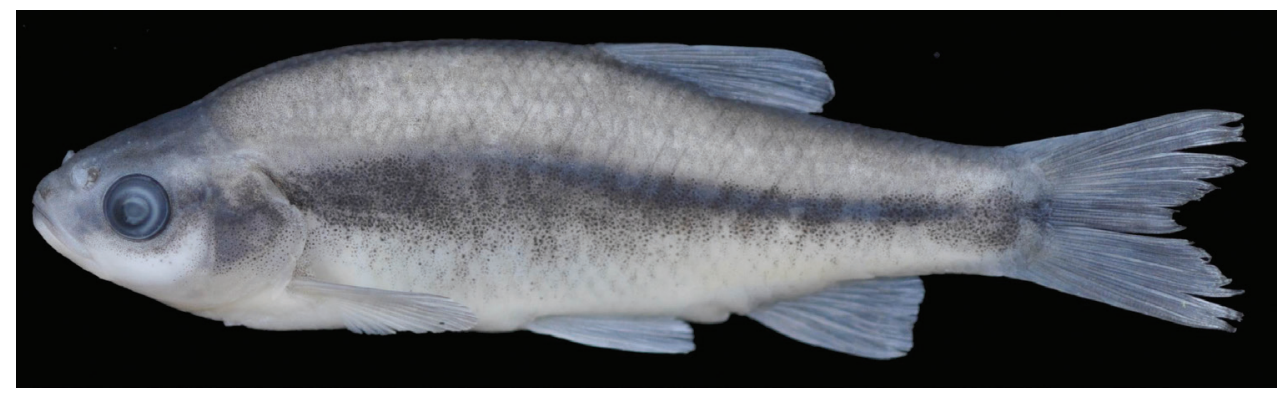

Figure 3. P. turani sp. n. paratype, IFC-ESUF 03-1003, $66.0 \mathrm{~mm} \mathrm{SL}$, Turkey: Hatay prov.: Hassa, İncesu Spring, Asi River drainage.

Table I. Morphometry of $P$. turani sp. n. (holotype IFC-ESUF 03-1002, paratypes IFC-ESUF 03-1003, $\mathrm{n}=20$ ) and $P$. kervillei (IFC-ESUF 03-0987, $\mathrm{n}=21$ ).

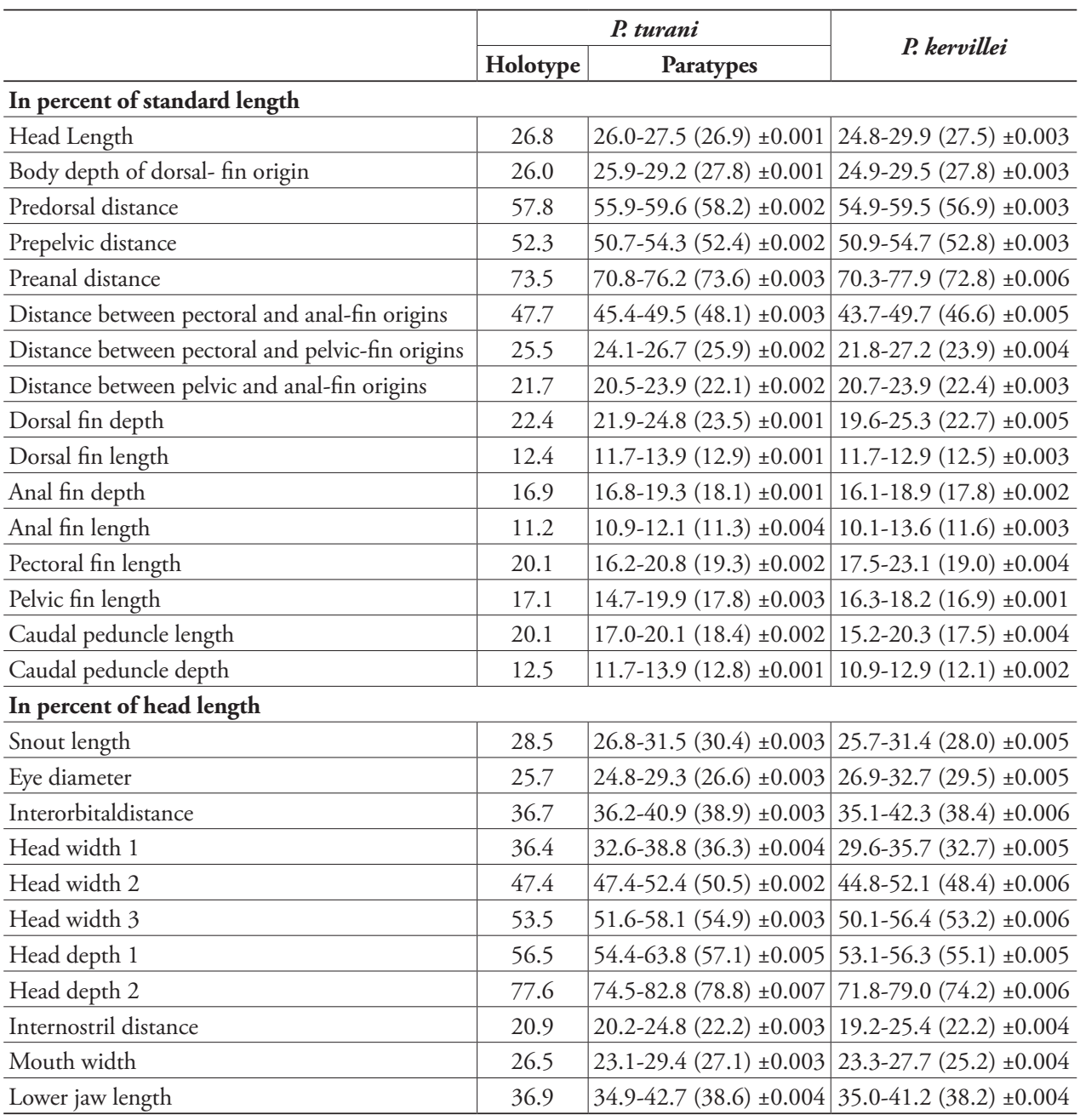


Table 2. Meristic features of the Eastern Mediterranean Region Pseudophoxinus species group (from comparative material).

\begin{tabular}{l|c|c|c|c|c}
\hline Species & $\begin{array}{c}\text { Lateral series } \\
\text { scales }\end{array}$ & $\begin{array}{c}\text { Lateral line } \\
\text { scales }\end{array}$ & Pharyngeal teeth & Gill rakers & Vertebral formula \\
\hline P. firati & $41-49+1-2$ & $35-51$ & $5-5(4)$ & $6-7$ & $37-38: 22+16-17$ \\
\hline P. kervillei & $37-44+2-3$ & $4-17$ & $5-4$ & $7-8$ & $35-36: 19-20+16-17$ \\
\hline P. turani sp. n. & $\mathbf{3 8 - 4 6 + 2 - 3}$ & $\mathbf{1 2 - 2 5}$ & $\mathbf{5 - 4}$ & $\mathbf{8 - 1 1 ( 1 3 )}$ & $\mathbf{3 6 - 3 8 : 2 1 - 2 2 + 1 6 - 1 7}$ \\
\hline P. zekayi & $40-46+1-2$ & $36-43$ & $5-5$ & $7-9$ & $37-39: 21-22+15-17$ \\
\hline P. zeregi & $54-59+2-3$ & $47-53$ & $5-4$ & $7-9$ & $36-38: 19-21+16-17$ \\
\hline
\end{tabular}

mean 30.4, greater than eye diameter. Caudal-peduncle length 17-20\% SL, mean 18.4; caudal-peduncle length 1.3-1.7, mean 1.5, times its depth. Lateral line incomplete, commonly not reaching the level of anus, $12-25$ perforated scales, $38-46+2-3$ scales in lateral series. Dorsal fin with 3 simple and $71 / 2$ branched rays, outer margin straight or slightly convex. Anal fin with 3 simple and 61/2 ( 2 specimens)-71/2 (19 specimens) branched rays, outer margin straight or slightly convex. Pectoral fins with 11-12 (rarely 13) branched rays, outer margin convex. Pelvic fins with 6 branched rays, outer margin convex. Caudal fin forked, lobes rounded. No pelvic axillary lobe and keel between posterior pelvic fin base and anus. Pharyngeal teeth 5-4, slightly serrated, hooked at tip. Gill rakers short, with 8-11 (rarely 13) on outer side of first gill arch. Scales oval, with numerous radii posteriorly. Total vertebrae 36-38, 21-22 abdominal and 16-17 caudal vertebrae, vertebral formulae: 36-38:20-21+16-17.

Sexual dimorphism. There is no sexual dimorphism between males and females

Coloration. Ground color of formalin-preserved adults and juveniles dark grey on back and upper part of flank, yellowish on lower part of flank and belly. Dark grey stripe (its width 1 to 2 times eye diameter) on the middle of flank from posterior margin of operculum to caudal peduncle, distinct in both anterior and posterior parts of body. Caudal, dorsal and anal fins grey; pectoral and pelvic fins light grey. Black spots present on rays of all fins, additionally on the dorsal-fin base. A small black blotch of pigment present on caudal-fin base. Peritoneum grayish to blackish, with numerous crystal-shaped black spots.

Etymology. The species is named after Davut Turan (Recep Tayyip Erdoğan University, Rize), in appreciation for his contributions to our knowledge of the fish fauna of Anatolia.

\section{Discussion}

As stated by Küçük et al. (2013), unlike the central and western Anatolian species, which differ from one another in complex morphological features, the Eastern Mediterranean Pseudophoxinus species (mentioned as Levant species) are morphologically quite similar with the exception of $P$. zekayi, which differs from the others in having a complete lateral line. 


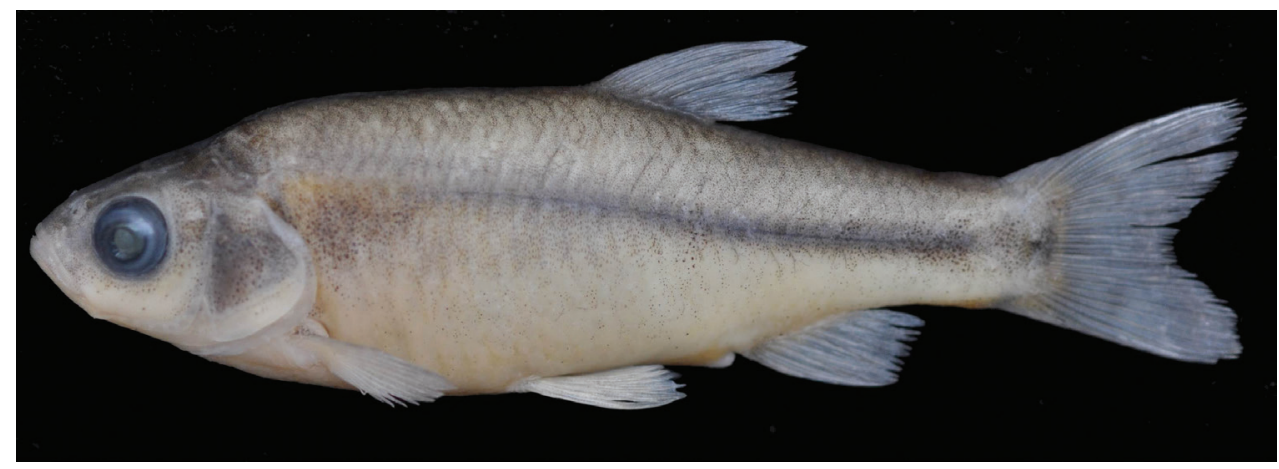

Figure 4. P. kervillei IFC-ESUF 03-0987, $73.2 \mathrm{~mm}$ SL, Turkey: Hatay prov.: Lake Gölbaş1, Asi River drainage.

Below we compare $P$. turani from the İncesu Spring, a drainage of Asi River, with the Eastern Mediterranean region Pseudophoxinus species group: P. kervillei from Gölbaşı Lake (Asi River drainage), P. zekayi from Aksu Stream (Ceyhan River drainage), P. zeregi from Sinnap Stream (Kuveik River drainage), and P. firati from Tohma Stream (Furat River drainage) (Pellegrin 1911; 1928; Bogutskaya 1997; Bogutskaya et al. 2007). Pseudophoxinus turani is easily distinguished from $P$. kervillei by its terminal mouth (vs. slightly superior) and rounded snout (vs. slightly rounded). It is further distinguished from $P$. kervillei by having more gill rakers on the outer side of the first gill arch (8-11, rarely 13, vs.7-8), usually more lateral-line scales (12-25, vs. 4-17), more abdominal vertebrae (21-22, vs. 19-20), usually more total vertebrae (36-38, vs. 35-36) and sometimes fewer branched pelvic-fin rays (6 vs. 6-7). Besides the differences listed above $P$. turani has a smaller eye diameter and longer snout than $P$. kervillei.

Pseudophoxinus turani and P. kervillei were also compared by Principal Component Analysis (PCA) using 27 morphometric characters. The PCA clearly separated Pseudophoxinus turani from P. kervillei (Fig. 5). Variables loading on the first metric PC I-II are given in Table 3.

Pseudophoxinus turani is distinguished from $P$. zeregi by having fewer lateral-line scales (12-25, vs. 47-53), fewer lateral series scales $(38-46+2-3$, vs. 54-59+2-3), fewer scales between lateral line and dorsal-fin origin (10-11, vs.11-13) and usually more gill rakers on first gill arch (8-11, rarely 13, vs. 7-9). In Pseudophoxinus turani, membranes of fins are grey and rays have black spots, while in P. zeregi membrane of fins are hyaline and rays lack black spots.

Pseudophoxinus turani is clearly separable from $P$. zekayi by having an incomplete lateral line (vs. complete), fewer lateral-line scales (12-25 vs. 36-44), fewer pharyngeal teeth (5-4, vs. 5-5) and a longer snout (28.5-31.7\% HL, mean 30.3, vs. mean 26.01 $\% \mathrm{HL}$ ). In $P$. turani, eye diameter is smaller than snout length while in P. zekayi, eye diameter is equal to or greater than snout length.

Pseudophoxinus turani is distinguished from P. firati by having fewer lateral-line scales (12-25 vs. 35-51) and more gill rakers on the outer side of the first gill arch 


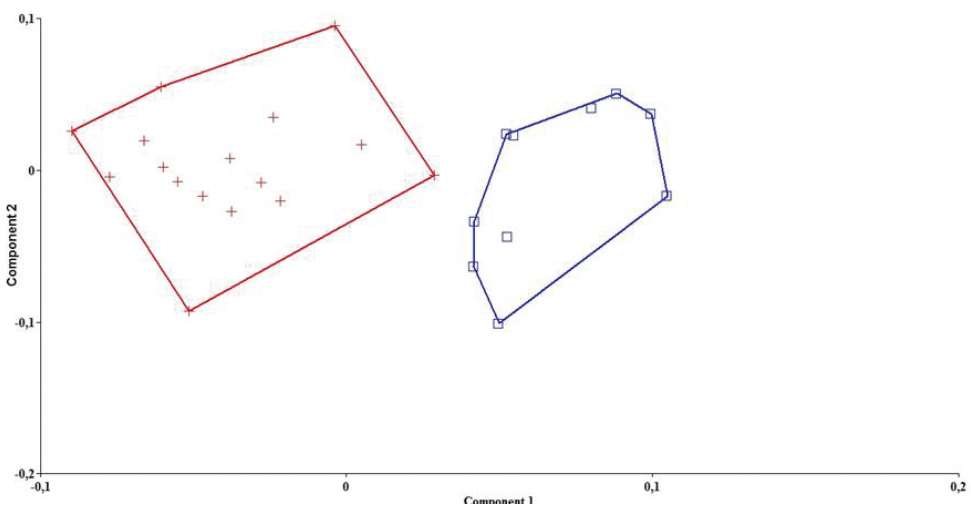

Figure 5. A scatter plot of the scores of the first two principal components (PC I, PC II) for 28 specimens of two Pseudophoxinus species, P. turani sp. n. (+) and P. kervillei ( $\square)$, based on 27 morphometric characters.

Table 3. Character loading on principal components I-II for 27 measurements taken on 28 specimens of two Pseudophoxinus species (P. turani sp. n. and P. kervillei).

\begin{tabular}{l|c|c}
\hline \multicolumn{3}{c}{ Morphometric features } \\
\hline In percent of standard length & PC I & PCA II \\
\hline Head Length & 0.052 & -0.162 \\
\hline Body depth of dorsal- fin origin & -0.030 & -0.144 \\
\hline Predorsal distance & -0.104 & -0.043 \\
\hline Prepelvic distance & 0.006 & -0.048 \\
\hline Preanal distance & -0.055 & -0.096 \\
\hline Distance between pectoral and anal-fin origins & -0.128 & -0.143 \\
\hline Distance between pectoral and pelvic-fin origins & -0.296 & -0.084 \\
\hline Distance between pelvic and anal-fin origins & 0.011 & -0.259 \\
\hline Dorsal fin depth & -0.161 & -0.101 \\
\hline Dorsal fin length & -0.099 & 0.021 \\
\hline Anal fin depth & -0.060 & 0.074 \\
\hline Anal fin length & 0.274 & 0.166 \\
\hline Pectoral fin length & -0.106 & -0.306 \\
\hline Pelvic fin length & -0.231 & 0.095 \\
\hline Caudal peduncle length & -0.243 & 0.132 \\
\hline Caudal peduncle depth & -0.275 & -0.208 \\
\hline In percent of head length & & \\
\hline Snout length & -0.327 & 0.138 \\
\hline Eye diameter & 0.363 & 0.261 \\
\hline Interorbitaldistance & -0.022 & 0.209 \\
\hline Head width 1 & -0.426 & 0.077 \\
\hline Head width 2 & -0.130 & 0.124 \\
\hline Head width 3 & -0.128 & 0.076 \\
\hline Head depth 1 & -0.172 & 0.129 \\
\hline Head depth 2 & -0.249 & 0.181 \\
\hline Internostril distance & 0.027 & 0.356 \\
\hline Mouth width & -0.136 & 0.491 \\
\hline Lower jaw length & 0.006 & 0.253 \\
\hline & &
\end{tabular}


(8-11, rarely 13 , vs. 6-7). P. turani is also distinguished from $P$. firati by having a black spot on base of caudal fin (vs. lacking), slightly shorter head length (26.0-27.5, mean 26.9 \%SL, vs. mean 28.6), 3 simple dorsal-fin rays (vs. commonly 4), and more scales between lateral-line and dorsal-fin origins (10-11, vs. commonly 9).

Our data on meristic features of the Eastern Mediterranean Pseudophoxinus (Table 2) are largely compatible with previously published counts: Heckel (1843) counted 57-66 perforated scales on the lateral line of the type species, $P$. zeregi, from the Kuveik River near Aleppo, whereas we counted 47-53 scales in our material from Sinnap Stream (Kuveik River drainage) (We believe that Heckle (1843) were counted scales in lateral series along the midlateral line). Lateral series and lateral line scale counts of $P$. kervillei are compatible with that of Pellegrin (1928) and Küçük et al. (2013). Meristic data of P. frati and P. zekayi are also found largely to be in conformity with Bogutskaya et al. (2007) and Küçük et al. (2013).

\section{Comparative material (all from Turkey)}

P. firati: IFC-ESUF 03-0999, 12, 34.6-51.7 mm SL, Sivas prov.: Firat River drainage, Yazyurdu, M.A. Atalay, 04 August 2004;03-1001, 4 (paratypes),41.2-47.7 mm SL, Sivas prov: Firat River drainage, Tohma Stream at Yazyurdu, T. Hrbek, K.N. Stölting, R.H. Wildekamp and A. Meyer, ? April 2000.

P. kervillei: IFC-ESUF 03-0987,26, 60.7-84.9 mm SL, Hatay prov.: Lake Gölbaş1Kırıkhan, F.Küçük, D.Turan, S.S. Güçlü, 01 July 2012; 03-0988, 25, 27.4-56.0 mm SL, Hatay prov.: Meydan Village-Samandağ, F.Küçük, D.Turan, S.S. Güçlü, H.Temizkan, 30 June 2012.

P. zekayi: IFC-ESUF 03-1007, 32, 28.5-62.1 mm SL, Kahramanmaraş prov.: Aksu Stream, F.Küçük, D.Turan, S.S. Güçlü, 29 June 2012.

P. zeregi: IFC-ESUF 03-1011, 47, 33.9-64.5 mm SL, Kilis prov.: Sinnap Stream, F.Küçük, D.Turan, S.S. Güçlü, M. Kamer, C. Kaya, 04 November 2012 and 26 June 2013; IFC-ESUF 03-1012, 4, 36.3-64.5 mm SL, Kilis prov.: Sinnap Stream, İnanlı Village, C. Kaya, E. Gürlek, 26 June 2013.

\section{References}

Bogutskaya NG (1997) Contribution to the knowledge of leuciscine fishes of Asia Minor. Part 2. An annotated check-list of leuciscine fishes (Leuciscinae, Cyprinidae) of Turkey with descriptions of a new species and two new subspecies. Mitteilungen aus dem Hamburgischen Zoologischen Museum und Institut 94: 161-186.

Bogutskaya NG, Küçük F, Atalay MA (2007) A description of three new species of the genus Pseudophoxinus from Turkey (Teleostei: Cyprinidae: Leuciscinae). Zoosystematica Rossica 15: 335-341.

Hammer O, Harper DAT, Ryan PD (2001) PAST: paleontological statistics software package for education and data analysis. Palaeontologia Electronica 4: 9. 
Hrbek T, Stölting KN, Bardakçı F, Küçük F, Wildekamp RH, Meyer A (2004) Plate tectonics and biogeographical patterns of the Pseudophoxinus (Pisces: Cypriniformes) species complex of central Anatolia, Turkey. Molecular Phylogenetics and Evolution 32: 297-308. doi: 10.1016/j.ympev.2003.12.017

Kottelat M, Freyhof J (2007) Handbook of European freshwater fishes. Kottelat, Cornol and Freyhof, Berlin, xiv $+646 \mathrm{pp}$.

Krupp M (1985) Sistematik und zoogeographie der Süsswasserfische des levantinischen Grabenbruchsystem und Ostküste des Mittelmeers. Dissertion, vol. 1, 2. Mainz, 215+169 pp. Küçük F, Atalay MA, Güçlü SS, Gülle İ (2013) The Morphological Characteristics of Pseudophoxinus (Teleostei: Cyprinidae) Species Distributed in Turkey and Zoogeographic Distribution (In Turkish). Süleyman Demirel Üniversitesi Eğirdir Su Ürünleri Fakültesi Dergisi 8(2): 1-9. [Date of Publication: December 2013 [in Turkish]]

Naseka AM (1996) Comparative study on vertebral column in the Gobioninae (Cyprinidae, Pisces) with special reference to its systematics. Publicaciones Especiales Instituto Espanol de Oceanografia 21: 149-167.

Pellegrin J (1911) Poissons de Syrierecueillis par M.H. de Kerville. Bulletin de la Société Zoologique de France 36:107-111.

Pellegrin J (1928) Les Poissons des Eaux Doucesd'Asie-Mineure.Lab. au Museum National d'Historie Naturella Paris, 150 pp.

Perea S, Bohme M, Zupancic P, Freyhof J, Sanda R, Özuluğ M, Abdoli A, Doadrio I (2010) Phylogenetic relationships and biogeographical patterns in Circum-Mediterranean Subfamily Leuciscinae (Teleostei, Cyprinidae) inferred from both mitochondrial and nuclear data. BMC Evolutionary Biology 10(1): 265. doi: 10.1186/1471-2148-10-265 